\title{
Experimental Animal Models in Periodontology: A Review
}

\author{
Xavier Struillou ${ }^{1}$, Hervé Boutigny ${ }^{1}$, Assem Soueidan ${ }^{1}$, and Pierre Layrolle ${ }^{2,3, *}$ \\ ${ }^{I}$ Department of Periodontology, Faculty of Dental Surgery, University of Nantes, 1 Place Alexis Ricordeau, 44042 \\ Nantes, France \\ ${ }^{2}$ Inserm, U957, LPRO, Faculty of Medicine, University of Nantes, 1 rue Gaston Veil, 44035 Nantes, France \\ ${ }^{3}$ ERT 2004, Clinical Research in Odontology and Osteoarticular, Faculty of Dental Surgery, University of Nantes, 1 \\ Place Alexis Ricordeau, 44042 Nantes, France
}

\begin{abstract}
In periodontal research, animal studies are complementary to in vitro experiments prior to testing new treatments. Animal models should make possible the validation of hypotheses and prove the safety and efficacy of new regenerating approaches using biomaterials, growth factors or stem cells. A review of the literature was carried out by using electronic databases (PubMed, ISI Web of Science). Numerous animal models in different species such as rats, hamsters, rabbits, ferrets, canines and primates have been used for modeling human periodontal diseases and treatments. However, both the anatomy and physiopathology of animals are different from those of humans, making difficult the evaluation of new therapies. Experimental models have been developed in order to reproduce major periodontal diseases (gingivitis, periodontitis), their pathogenesis and to investigate new surgical techniques. The aim of this review is to define the most pertinent animal models for periodontal research depending on the hypothesis and expected results.
\end{abstract}

Keywords: Periodontal disease, animal models, biomaterials, periodontal surgery.

\section{INTRODUCTION}

The presence of oral bacterial biofilm in gingival and periodontal tissues provokes an immune-inflammatory response that can result in the progressive destruction of the structural components of the periodontium. This condition leads to the clinical signs of periodontitis, with the breakdown of the tooth-supporting structures until tooth loosening. In order to arrest the progression of the disease, scaling and root-planning are performed, together with rigorous oral hygiene. The objective of periodontal treatment should ultimately be to regenerate the periodontal tissue by using non surgical or surgical techniques, biomaterials for guided tissue regeneration, bone substitutes (e.g. Calcium phosphates or others), growth factors (e.g. enamel matrix derivatives) or, as more recently proposed, mesenchymal stem cells [1]. Appropriate experimental animal models are required for testing and validating new regenerative therapies for damaged periodontal tissues. Animal studies are effectively complementary to in vitro experiments prior to testing new clinical treatments where biopsy harvesting for histology is generally not accepted in human. Different animal species could be used for modeling periodontitis and treatments, but primates, dogs, rats, rabbits, pigs, hamsters and ferrets are the most commonly employed. Experimental animal models should be used with care, particularly primates and canines, for ethical reasons [2, 3]. It may be preferable to use small animals

*Address correspondence to this author at the Inserm U957, Faculty of Medicine, Nantes, France; Tel: + 332726411 43; Fax: +33 2404128 60; E-mail: pierre.layrolle@univ-nantes.fr (e.g. rats, hamsters, rabbits, ferrets) but their physiopathology is not as similar as humans and so, experimental models needs to be reproducible in order to obtain relevant results.

Research in periodontology involves different strategies, principally the etiology of periodontal diseases using experimental models of periodontitis, and the regeneration of damaged periodontal tissues by surgically creating bone defects in combination, or not, with experimental periodontitis. The outcomes of animal studies using new biomaterials and therapies designed for medical applications other than periodontal diseases, such as filling bone defects in orthopedics, are not particularly valuable in the specific periodontal context. Periodontal lesions effectively appear as open and non vascularized cavities with chronic inflammation in the tissues and specific experimental models should thus be used. Concerning etiopathologic studies, non-human primates are preferred but large series are not ethically and economically acceptable. Small animal models (e.g. rats or hamsters) have been developed for periodontal research but these studies mainly focus on bacteriology and immune response.

Depending on species, periodontal diseases could be induced spontaneously, experimentally or both. In the context of regenerative medicine using biomaterials, large animal models have been preferred due to the reproducibility and surgical accessibility of experimental defects. Apart from monkeys, which are the ideal model in pre-clinical studies, dogs have been widely used for modeling the regeneration of periodontal defects with biomaterials. Some studies have also used rats, mini-pigs, sheep, rabbits and cats. Different methodologies have been proposed in order to ensure reproducible models that make statistical analysis possible. 
Table 1. Decision Making of Laboratory Animal Model

\begin{tabular}{|c|c|c|c|c|c|}
\hline \multirow[b]{2}{*}{$\begin{array}{c}\text { Pertinence of the } \\
\text { Model }\end{array}$} & \multicolumn{3}{|c|}{ Research Based on Pathogenesis of Periodontal Disease } & \multicolumn{2}{|c|}{$\begin{array}{c}\text { Research Based on Periodontal Treatment } \\
\text { Modalities }\end{array}$} \\
\hline & Disease etiology & Calculus & $\begin{array}{l}\text { Immunology and } \\
\text { Micriobiology }\end{array}$ & Biomaterials & Implant \\
\hline Non Human Primates & Excellent & Medium & Excellent & Excellent & Good \\
\hline Rabbit & Low & Low & Low & Medium & Medium \\
\hline Ferret & Medium & Good & Low & Low & Low \\
\hline Rat & Low & Medium & Good & Medium & Low \\
\hline
\end{tabular}

The aim of this review is to summarize the animal models used for periodontal research. The first part concerns the choice of the most suitable animal model related to expected results. In the second part, the different animals will be detailed, describing their anatomy, physiopathology of periodontal disease and their preferential interest in periodontal research.

\section{SELECTION OF ANIMAL MODELS FOR PERIO- DONTAL RESEARCH}

The selection of an experimental model is determined by research objectives, as well as laboratory constraints such as housing of large or non standard animals. The use of large animals with ethical and social issues such as monkeys and dogs should be reserved for last phase validation of new treatments prior to use in human clinical practice. In most cases, small animal models such as rats or hamsters will be sufficient to assess the role of bacteria, diet or other factors in periodontal inflammation at the histological level, providing sufficient statistical significance and pre-clinical relevance.

Table 1 summarizes the different animal models used in periodontal research. The relevance of animal models for studying periodontal diseases, biomaterials, dental implants, or new regenerative strategies is indicated.

\section{EXPERIMENTAL GINGIVITIS AND PERIODON- TITIS}

In order to study the origin and evolution of periodontal diseases, the animal model should have characteristics for the disease process that are similar to those encountered in humans. These experimental etiopathogenics studies should use indices similar to those in clinical practice: gingival index, calculus index, depth of subgingival pockets, tooth loosening. These experimental data may be completed with radiographs, blood immunology assays, bacteria determination and histology analysis.

Experimental studies conducted in monkeys are highly relevant for human clinical practice as they present comparable anatomy and develop similar periodontal diseases with similar clinical symptoms. However, experimental research in monkeys requires a strong ethical justification of their care and use and should take into account the purchasing, transportation and housing expenses of these animals over long periods.

The occurrence of periodontal diseases in dogs is high, increases with ageing and thus, the etiopathology is closely related to humans [4]. Although there are certain differences in the inflammatory response as well as in the bacterial population, dogs are widely used in gingivitis and periodontitis research. Calculus deposits lead to gingivitis [5] but contrary to humans, the sub-connective tissue remains almost normal in dogs. The conversion from gingivitis to periodontitis is not systematic but could be experimentally induced by fixing ligatures around the teeth $[6,7]$.

Rodents and rats in particular, are ethically relevant models for experimental periodontal research. The structure of the dental gingival area is quite similar to that observed in humans [8]. However, the occurrence of periodontal diseases in rats is less frequent than in human, although the pathology can be induced by inoculating bacteria, giving a carbohydrate-rich diet and fixing ligatures around the teeth. This experimental model is not optimal for studying the evolution of the disease over long periods using histology because of the continuous growth and migration of the teeth. This model is widely used for microbiological and immunological studies [9]. In addition, the use of gnobiotic or germ-free animals appears to be very interesting for the opportunities they give for carrying out mono-infections by periodontopathogens bacteria of human origin.

The etiopathology of periodontal diseases in hamsters is similar to that in rats. Experimental periodontitis is easily obtained by feeding animals with a carbohydrate-rich diet. In this model, research focuses on microbiology and immunology [10].

\section{CALCULUS}

Although monkeys are the most closely related model to humans, research on calculus has mainly been conducted on dogs, rats or ferrets. Abundant calculus deposits associated with periodontitis was observed in aged dogs. This model is therefore of value for testing different techniques for remov- 


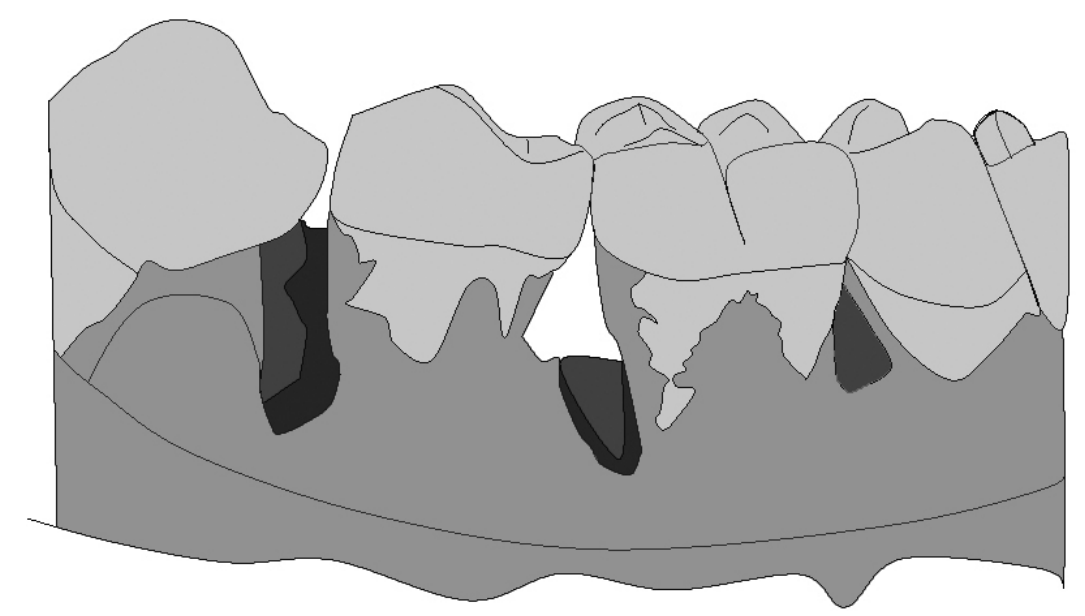

Fig. (1). Intrabony defects on mesial root of monkey mandibular molars as described by Sculean et al. 2000.

ing subgingival calculus. Rats and hamsters with appropriate feeding develop dental and subgingival calculus making research possible on large numbers of animals.

\section{SURGICAL PERIODONTAL DEFECTS AND TREATMENTS}

Different biomaterials and tissue regenerative treatments have been tested in large pre-clinical models, mainly monkeys and dogs and to some extent in pigs and rabbits. A literature research on Medline (key words: experimental periodontal disease, various animals such as dog, surgical techniques such as regeneration, biomaterials) gave about 200 publications, in the last ten years (1999 to 2009), in experimental periodontitis using biomaterials (guided tissue regeneration, grafting biomaterials or enamel matrix proteins) and tissue engineering. Most of these papers published in the last decade concern new materials as enamel matrix proteins or BMP, compared to standard procedures as guided tissue regeneration or grafting material, used to evaluate histologically the regeneration of periodontal tissues. Thus, the information obtained allows the passage to clinical use in humans.

The selection of these animals was based on similar pathologies and the ease of surgically created clinicallyrelevant defects. Experimental periodontal defects may be obtained in three different ways [11]: (i) the acute defect model, (ii) the chronic defect model and (iii) the acute/chronic defect model. In the acute model, all defects are surgically-induced by removing surgically all the periodontal components (bone, cementum and periodontal ligament). Reproducible defects in experimental and control sites are created. In the chronic model, lesions are obtained by placing orthodontic elastics, silk sutures or ligatures around teeth during 12 to 20 weeks, depending on the type of animal studied. These defects are deeper in the interproximal spaces than in the buccal or lingual surfaces. In the combined acute/chronic model, the defects are surgically-created and ligatures are placed to ensure calculus accumulation and to prevent spontaneous regeneration of the defects. Periodontal and osseous defects are created at the alveolar crest of the ramus bone. These studies concern critical-sized defects that will not spontaneously heal during the study in order to prevent bias. The size of the defect depends on the anatomy and physiology of the species considered. The most commonly used models in periodontal research are monkeys and dogs.

\section{THE DIFFERENT ANIMAL MODELS IN PERIO- DONTOLOGY}

The animals used in periodontal research have a different anatomy, dentition and structure of periodontal tissues. Furthermore, the physiopathology, oral bacteria and inflammation response vary between species.

\section{1) Non-Human Primates}

Monkeys have the advantage of probably being philogenetically similar to humans. All non-human primate species offer a wide range of sizes: from about 300 to 350 gram for certain marmosets, to sizes similar to humans for the largest such as chimpanzees and gorillas. All these species are diphyodont. Macaques, baboons and chimpanzees have the same dental formula as human: I 2/2, C 1/1, Pm 2/2 and M $3 / 3$. However, marmosets have a different formula with I $2 / 2, \mathrm{C} 1 / 1, \mathrm{Pm} 3 / 3$ and $\mathrm{M} 2 / 2$. The anatomy of teeth and roots is close to that of humans, but the size is smaller. The canines in most non-human primates are elongate and prehensile. In gorillas and baboons, the premolars have more than one root.

Certain species of non-human primates have periodontal diseases at an adult age [12]. Histologically, the structure of the periodontium is also similar to that observed in humans. Microbiologically, in Macaca fascicularis (cynomolgus monkeys), the composition of the plaque is Gram positive rods and cocci for supragingival plaque and anaerobic Gram negative rods for subgingival plaque $[13,14]$. The inflammatory response to periodontal disease is quite similar to that found in humans. Connective tissues are infiltrated by plasma cells, lymphocytes and neutrophils. In other species, such as squirrel monkeys and marmosets, there is very limited inflammatory infiltrate. These major differences with humans make them inappropriate models for studying the pathogenesis of periodontitis [15]. Nevertheless, the marmoset has been the most frequently-used non-human primate in periodontal research.

In the last ten years, 25 articles have been published using monkeys for research relating to periodontal healing [16$18]$ filling with biomaterials $[19,20]$, guided tissue regenera- 
tion [21], enamel matrix derivatives [22-24], or implant surgery [25-31]. These surgical approaches, are, for the most part, carried out on Macaca fascicularis. All the teeth can be used, which makes it possible to obtain an important number of test sites, with a limited number of animals. For example, in the study by Sculean et al. [23], 24 lesions (intraosseous and fenestration defects) were created at the level of the incisors and premolars in only 3 monkeys. The intraosseous defects $(n=18)$ were located in the mesial part of each tooth and had a depth of between 6 and $8 \mathrm{~mm}$ (Fig. 1). In order to prevent any spontaneous healing and to promote plaque accumulation, metal strips were placed in the defects and were attached to the teeth using a composite material. Standardized critical-sized defects of the fenestration type $(n=6)$ were made in the same monkeys. The defects were treated by guided tissue regeneration (GTR) or by induced guided regeneration by enamel matrix proteins (EMD). Control defects were treated with coronally repositioned flaps. This model is quite similar to those used in clinical human studies, and, for this reason, appears to be a pertinent animal model.

Class III furcation lesions can also be used as surgical periodontal model in the mandibular molars of monkeys [32].

Monkeys were used because they present anatomical similarities with humans. However, it is difficult to obtain a large number of animals and it is thus imperative that a maximum number of defects be created in order to obtain a sufficient quantity of test and control sites to make adequate statistical analysis of the results possible. Moreover, ethical considerations and regulations should be fulfilled in order to prevent any trafficking of protected species.

\section{2) Dogs}

Many experimental studies on gingival and periodontal diseases have been conducted in dogs. The beagle is one of the most commonly used due to its size and its extremely cooperative temperament. Globally, all periodontal tissues and the size of the teeth are quite similar to those observed in humans. However, some major differences exist between dogs and humans as the lack of lateral movements, no occlusal contacts for all the premolars and presence of open contacts between teeth. The frequent lack of gingival sulci and crevicular fluid, a different composition of periodontal plaque and calculus are other important differences between dogs and humans [33]. All dogs are diphyodont with deciduous and permanent dentition. The formula for permanent dentition is I 3/3, C1/1, Pm 4/4, M 2/3. All domestic dogs have a natural susceptibility to periodontal diseases in adult age but may be maintained healthy by appropriate plaque control. Periodontal alterations, including gingivitis and periodontitis, increase in prevalence and severity with age, faster than in man but with the same etiologic factors. Gingivitis may be generalized and associated with bleeding on probing, the presence of supragingival and subgingival plaque, calculus and severe bone loss including osseous defects. Currently, gingival recessions appear in the severe forms of periodontal diseases in dogs. Supragingival plaque is mostly composed of Gram positive cocci. The subgingival flora is mainly anaerobic Gram negative cocci and rods
(Porphyromonas gingivalis, Fusobacterium nucleatum, Capnocytophaga).

Gingivitis in dogs may be accelerated by an appropriate soft, minced diet, promoting the accumulation of supragingival plaque and calculus [34-37]. In healthy dogs, the gingival sulcus is most frequently absent. The junctional epithelium and epithelial attachment extend to the most coronal level on the gingival margin. In early gingivitis, the inflammation is limited to this marginal part of the gingival tissue with the presence of neutrophils and monocytes leaving most of the connective tissue free of infiltrate. At the later stages, the infiltrate extends apically subjacent to the junctional epithelium with the formation of gingival pockets.

Periodontitis in dogs occurs on the basis of pre-existing gingivitis. There is a formation of periodontal pockets lined with typical pocket epithelium. In the connective tissue, the dense cellular infiltrate consists mainly of plasma cells and lymphocytes. The osteoclastic resorption of alveolar bone may result in deep, narrow lesions extending vertically around a single root leaving the interdental space intact [38, 39]. The bone defect can involve the furcation areas of premolar and molar teeth. In colony dogs, periodontitis appears earlier and more severely than in domestic dogs [40]. The bifurcation regions are more frequently deteriorated than the interdental spaces. The first and second premolars are the most frequently lost teeth.

In summary, the prevalence and severity of gingivitis and periodontitis in dogs increase with age but vary markedly between the different breeds. Some dogs are susceptible to periodontal disease and others are more resistant. The differences can be explained more by the nature of the infection or genetics than by diet. In these natural periodontal diseases, the extent and localizations of the periodontal lesions are not homogeneous [41], which may be considered to be a limitation for the model.

More than one hundred publications were found for periodontal research involving dogs for healing defects with various biomaterials, membranes, or with enamel matrix derivatives. A surgical model was proposed by Wikesjo in 1994 [42]. Critical-sized supra-alveolar defects [42, 43], measuring $6 \mathrm{~mm}$, were created at the level of the mandibular premolars (Fig. 2). The class III furcation defects thus obtained made it possible to test various regeneration procedures, whether or not they were associated with a filling biomaterial [44-46].

Two methodological approaches were described: treatment of surgical defects on the 3rd and 4th mandibular premolars [47-49], or a test based only on the 3rd premolar after avulsion of the 2 nd and 4th premolars [50-53]. These approaches were used to evaluate regeneration procedures using BMP, GTR, enamel matrix proteins or grafting materials as bioactive glass [54-57].

On the upper jaw, intraosseous defects on premolars and molars were also described $[45,58,59]$. The number of residual osseous walls present at the level of the surgical defect was considered to be an important factor for healing. Defects of $4 \mathrm{~mm}$ in width and depth with 1 or 3 osseous walls were regarded as reproducible and relevant models for evaluating biomaterials in periodontal regeneration $[60,61]$. The forma- 


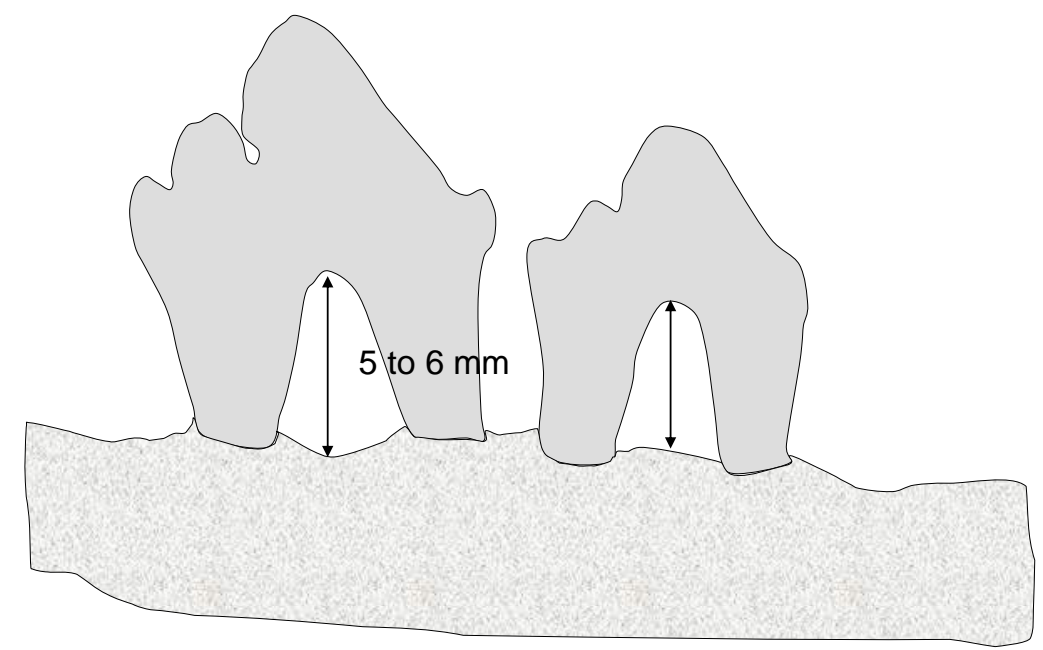

Fig. (2). Supraalveolar critical size periodontal defects on dog mandibular premolars as described by Wikesjo et al. 1994.

tion of critical-sized fenestrations on the buccal face of maxillary canines may also make it possible to evaluate filling biomaterials or regeneration techniques [62-67]. Defects in the form of dehiscence at the level of the buccal roots of the molars were also created in dogs [68]. Dogs also served as the animal model in muco-gingival surgery by creating recessions on the canines which were treated either by palatine connective tissue grafts, or by guided tissue regeneration [69-71].

Concurrently to these surgically-created lesions, it was also possible to obtain experimental periodontal defects by placing silk bindings around the teeth for a period of 4 to 6 months $[72,73]$ or to use spontaneous class II furcation defects occurring with periodontal disease in old dogs [74,75]. Combined techniques, such as placing bindings associated with surgical creation of periodontal defects, were also used to evaluate filling biomaterials and/or regeneration procedures [76, 77]. Dogs were also used as models in guided osseous regeneration [78, 79] and in implant surgery [80-82]. The ramic angle is also used in the implant approach, creating critical-sized defects filled with various biomaterials [83]. Peri-implantitis was induced by installing, for two months, bindings around dental implants. The osseous defects around the implants obtained in this way seemed relatively comparable with those observed in humans [84]. More recently, a study in dogs has reported research on mesenchymal stem cells and tissue engineering in the treatment of periodontal diseases [85-88]. In summary, the most commonly used animal model in periodontal research seems to be dogs due to reproducible critical-sized defects.

\section{3) Rats}

The rat is the most extensively-studied rodent for the pathogenesis of periodontal diseases. Typical rodent dentition is $\mathrm{I} 1 / 1, \mathrm{C} 0 / 0, \mathrm{Pm} 0 / 0, \mathrm{M} 3 / 3$. The incisor is rootless. The structure of the dental gingival area in rats is quite similar to that observed in humans [8], with a shallow gingival sulcus and attachment of the junctional epithelium to the tooth surface. However, there are some differences: the first is the keratinisation of the crevicular epithelium in rats; the second is the relationship between the gingival and junc- tional epithelium with desmosomal contact between the most superficial cells of the gingival epithelium and the non keratinized cells of the junctional epithelium [89]. Despite this structural difference, the junctional epithelium appears to be a pathway for foreign substances, bacterial endotoxins, and for inflammatory cell exudations, similar to what occurs in humans.

As rats age, their dental tissues evolve, including continuous eruption of the teeth with permanent apposition of cementum and bone in relation to wear on all molar occlusion surfaces. All these phenomena cause a progressive shift in the position of the molars in three-dimensional space, resulting in global movement in an occlusal-distal-buccal direction compared to the occluso-mesial drift observed in humans. Wear on the occlusion surfaces leads to anatomical crown attrition and an increase in root length by apposition of cellular cementum. The cemento-enamel junction moves with time in an occlusal direction more rapidly than bone deposition at the alveolar crest. All components of the periodontal tissues are in permanent remodelling and the continuous occlusal-distal-buccal movement of rat molars appears to be a physiological expression of adaptive changes required by growth changes in the jaws and by rapid occlusal wear [15]. All these physiological and age-related phenomena have a strong impact on the interpretation of data obtained in experimental periodontal diseases, not only in rats but also in other rodents.

Under natural conditions, the rat appears to be extremely resistant to periodontal diseases, which is a remarkable difference with humans. Nevertheless, some strains may develop periodontitis by inoculation of specific bacteria, or with an appropriate diet, increasing the percentage of carbohydrates in food that accelerates the progression of the disease [15], or by fixing ligatures around the teeth (Fig. 3). The first step in periodontal alterations observed in diseasesusceptible strains is the appearance of marginal gingivitis with edema and ulcerations. Secondly, there is formation of deep pockets filled with food debris and hair. In severe degrees of periodontitis, the lesions affect the interradicular and interdental spaces with extensive alveolar bone resorption and denudations of the molar roots [15]. 


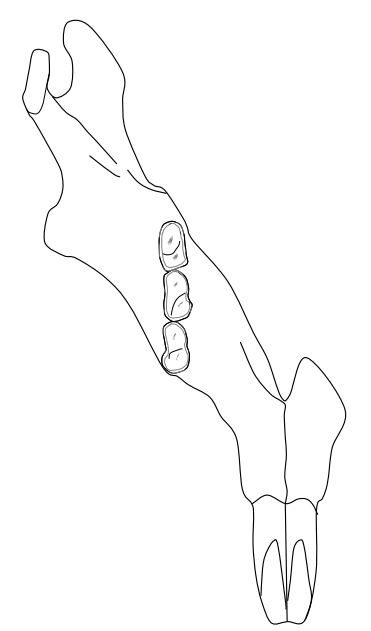

Fig. (3). Placement of silk or cotton ligatures around teeth on rats.

The most commonly-used strains are Wistar or the Spraque-Dawley. In periodontal disease-resistant strains, like germ-free Spraque-Dawley or white Lobund, experimental periodontitis may be obtained by using silk ligatures tied around the molars or by specific bacterial inoculations [90].

In rats, periodontitis appears to be an infectious process. Inoculations or injections of various periodontal pathogens such as Prophyromonas gingivalis, Aggregatibacter actinomycetemcomitans, Fusobacterium nucleatum, Capnocytophaga, Eikenella corrodens, Actinomyces viscosus, and Streptococus sobrinus can induce periodontal lesions [91]. After infection, the destruction of the periodontal tissue occurs quite rapidly. Inoculating Gram-negative bacteria induces a poor inflammatory response which is not similar to that found in humans. There are mainly neutrophils, few lymphocytes and an absence of plasma cells in the gingival tissues. Tissue destruction and host-response are different and depend on the type of bacterial agent applied. In rats, the appearance of gingivitis is not a systematic precursor of periodontal breakdown. At this initial stage, inflammation may only be localized around the junction epithelium. In this region, there is high phagocytic activity and neutrophils form a protective barrier. Bone resorption is then inconstant. Acute interdental inflammation characterized by an ulcerated junctional epithelium, infiltration of all supra-alveolar connective tissue by neutrophils and high osteoclastic activity has been observed in only about $10 \%$ of animals up to 100 days of age [92, 93]. The osseous defects observed were principally crater-like. The lesions were filled with bacteria in contact on one side with the entire root surface and on the other side, with residual connective tissue infiltrated by neutrophils, macrophages and lymphocytes. In Gram-negative infection, mainly periodontal lesions develop and quite early in the maxilla, later on the mandible. The appearance of severe crater-like bone defects may occur six to eight weeks after infection, and depends on the type of bacteria. The destructive process in response to Gram-negative bacteria can take place in the absence of cell-mediated immune response [94].

In the last 10 years, a surgical model in rats has been proposed [95]. As shown in Fig. (4), this model consists of surgically creating a periodontal defect in the form of fenestrations on the radicular surfaces of the second mandibular molars. After an extraoral incision, the bone in front of the second molars, as well as cement, were eliminated by using a burr under saline irrigation. The defects were standardized both in terms of depth $(1.5 \mathrm{~mm})$ and width $(3 \mathrm{~mm})$. This surgical model on the rat was reprised by Huang [96]. The rat was also used to evaluate the healing of supra and intraosseous defects after use of enamel matrix derivatives [97]. In these studies, standardized defects were created surgically in the roots of the first molars. The ramus area was also proposed to evaluate guided osseous regeneration techniques [98]. The toothless alveolar crest between the incisor and the first molar, or the edge of the mandible, are also interesting surgical models in guided osseous regeneration [24, 32]. Furthermore, rats are well accepted animals for experimental research. The breeding and housing costs are relatively low, making it possible to carry out studies with sufficient numbers for statistical analysis. However, the continuous occlusal eruption and osseous apposition on the dental roots makes the modelling and analysis of the results difficult and can result in significant bias. The use of rats in a surgical defect model seems promising, however, and should develop in the years to come [99].

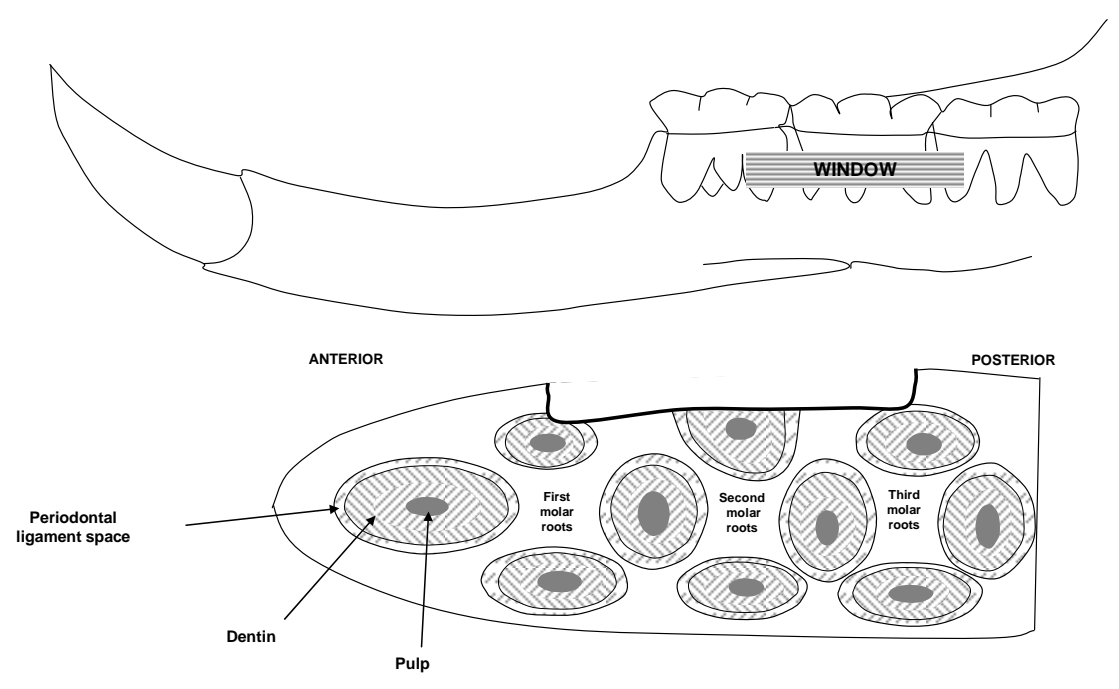

Fig. (4). Periodontal surgical defects on rats as described by King et al. 1997. 


\section{4) Hamsters}

In hamsters, periodontal disease does not occur spontaneously but may be obtained experimentally. The golden Syrian hamster is the most commonly used. The dentition formula is identical to rodents: I 1/1, C 0/0, Pm 0/0, M 3/3. As in rats, the molars move with time following the growth of the jaws and occlusal wear. The shift in the occluso-distal direction and the continuous eruption of molars seem to be less evident than in rats. Histologically, the structure of the periodontal tissue is very similar to that of rats [100] but due to the small size of this kind of animal, the interdental septum is narrower than in rats. Spontaneous periodontal disease was obtained using an appropriate diet containing high concentrations of carbohydrates, particularly sucrose [10]. With this specific diet, the plaque consisted of formic acid bacteria mixed with food debris, affecting principally the palatal and lingual surfaces, more than buccal. After plaque accumulation, there was a breakdown located at the junction epithelium and formation of crater-like gingival pockets. The inflammatory response consisted principally of neutrophils. Osteoclastic activity was stronger on the palatal and interdental side of the molar. Due to the small size of the interdental crest, bone resorption was almost exclusively horizontal with alteration of the interradicular spaces. The dynamics of alveolar bone resorption decreased significantly along the alveolar walls, and the palatal and lingual regions reacted more strongly than the buccal regions, which seemed quite inactive [101].

In summary, as in rats, the inflammatory response is very limited in hamsters and is very different from that observed in humans. The mechanisms of alveolar bone resorption in hamsters with diet-dependent periodontal lesions are quite similar to those observed in rats infected with Gram-positive bacteria.

\section{5) Ferrets}

Ferrets have a deciduous and permanent dentition. The formula is I $2 / 2, \mathrm{C} 1 / 1, \mathrm{Pm} 4 / 4, \mathrm{M} 2 / 2$. Ligature-induced periodontitis was obtained within 4 weeks $[102,103]$. The evolution in the periodontal lesions was quite similar to that observed in humans. As the disease progressed, calculus increased both in quantity and extent. The gingiva showed signs of inflammation. Secondly, after the junctional epithelium split, gingival pockets formed that were similar to those observed in hamsters. At the histological level, the connective tissue showed large numbers of neutrophils, plasma cells and lymphocytes. Alveolar bone resorption was severe, rating up to $50 \%$ [104].

\section{6) Minks}

The dentition formula of the adult mink is I $3 / 3, \mathrm{C} 1 / 1$, $\mathrm{Pm} 3 / 3$ and $\mathrm{M} 1 / 2$. In minks, spontaneous periodontitis, which is age- and plaque-dependent, is observed. Nevertheless, the extent of this periodontal disease appears to be severe only in very old animals. Ranch-raised minks may carry Chediak-Higashi syndrome (CHS), genetically transmitted by an autosomal trait [105]. Young adult minks with CHS have developed aggressive periodontitis, accompanied by severe periodontal lesions and bone loss. The extent of the gingiva was quite different between the maxilla and mandible. In the upper jaw, the vestibule was deep. The incisors and canines showed a large band of attached gingiva. The later is less important at the level of the premolars and molars. In the lower jaw, the amount of attached gingiva is narrow in the incisors and premolars. Around the molars, attached gingiva appeared to be comparable to that observed in the upper jaw [106]. In CSH-affected minks, periodontal disease occurs rapidly with a high hemorrhagic inflammatory response in the marginal gingiva. Bone resorption may be variable and associated with bone crater formation and furcation lesions, correlated with the location and extent of the gingival inflammation. Histologically, the inflammatory response appears to be quite different from that observed in humans with an acute exudative and persistent inflammatory reaction added to vascular proliferation. At the level of the marginal gingiva, there was proliferation of the blood vessels, all this zone was invaded by neutrophils. The epithelium extension into connective tissue was, in proportion, greater than in other species. The space occupied by connective tissue decreased dramatically. Plasma cells and lymphocytes were rare. In CHS-minks compared to normal minks, the quantity of neutrophils and small vessels, the extent and severity of the epithelial proliferation as well as bone resorption strongly increased. In minks, neutrophils play a key role in periodontal destruction due to deficiencies in the chemotactic response and massive release of lysosomal enzymes and proteases into periodontal tissue. Minks are therefore interesting experimental models in research on the etiology of periodontal diseases. Nevertheless, housing these animals may be difficult or require specific authorizations that may explain the absence of recent publications in the literature.

\section{7) Other Species}

Other animal models have been investigated for modelling periodontal diseases. For instance, mice have been studied but periodontal disease is very different to that observed in humans. The dental formula of mice is typical rodent dentition: I 1/1, C 0/0, Pm 0/0, M 3/3. Incisors have continuous growth and molars present complex physiological modifications with ageing. There is occlusal wear, bucco-occlusal motion and high hypercementosis at the apical part of each root [107]. Periodontal alterations are characterized by bone loss which is more severe at the lingual and palatal sides of the molars than at the buccal sides. There is also the presence of crater-like defects at the interdental and interradicular spaces. However, periodontal disease does not appear in mice younger than one year. The inflammatory response is relatively poor. The extensive physiological alterations in molar position in the alveolar socket over time mean that mice are not the best model for studying natural or induced periodontal disease.

Sheep have also been studied in the context of periodontal diseases. The permanent dentition of sheep consists of 32 teeth with a formula: I 0/3, C 0/1, Pm 3/3, M 3/3. The incisors have a very short root and are physiologically mobile. Periodontitis may affect these anterior teeth and is quite rapidly accompanied by deep periodontal pockets and severe bone loss. Histologically, the pocket wall is covered by a typical pocket epithelium. The connective tissue behind it is infiltrated by plasma cells. At the base of the pocket, the junctional epithelium is very short and connective tissue is infiltrated by neutrophils migrating to the apical plaque bor- 
der, then forming an interface layer [108]. The inflammation of the gingiva appears to be moderate. However there are no recent publications available using sheep as the animal model in periodontology.

Rabbits have mainly been used for testing biomaterials or for treatment of peri-implantitis. However, transcortical drilled holes creating tibial or radial critical-sized femoral defects are traditionally the most commonly used models in rabbits [109-111]. These defects in long bone are far from the specific situation of periodontal diseases but appear as a very interesting model for testing the bone healing.

One publication [112] used the cat as animal model. In this research, class III furcation defects were surgically created at the level of the premolars in order to study ankylosis at root level during periodontal healing.

Five studies have reported mini-pigs for research, mainly related to dental implant surgery and periodontal regeneration by enamel matrix derivatives [113, 114], as well as the effects of dental lasers on periodontal healing [115].

\section{CONCLUSION}

Experimental models for periodontal diseases are essential for understanding the origin and evolution of the pathology in humans. The use of animal models in periodontal research is a necessary step prior to entering into clinical trials with new biomaterials and treatments. The anatomy, physiology and pathogenicity of experimental models should relate as much as possible to those of patients in order to demonstrate the safety and efficacy of new biomaterials or treatments in periodontal regeneration. Monkeys are the models that are closest to human beings in terms of dental anatomy and physiology, but their use is limited by ethical and economic constraints. Experimental models in dogs have been widely used in periodontal research. As with monkeys, studies in dogs are difficult and protocols should rationalize the lesions as much as possible in order to obtain statistically exploitable data. Monkeys and dogs, as their anatomy and physiopathology are comparable to those of humans, should be restricted to pre-clinical studies for validating new treatments. Apart from these large animal models, smaller, easier to maintain and less expensive species have been proposed. Rats and hamsters develop experimental periodontal diseases. A surgical model for periodontal critical-sized defects in rats has been validated, making it possible to test new biomaterials in combination with growth factors or mesenchymal stem cells. The use of gnobiotic or germ-free rats is a major model for all research on the microbiology of periodontal diseases. In the same way, the gilded hamster remains an interesting model for any immunological research. However, the continuous growth of the teeth in rodents makes the modeling more difficult to understand, but this problem seems to have been solved in this last decade. New avenues are now available in periodontal research, allowing larger cohorts that are easier to maintain. A more systematic use of these small animal models appears evident for future research, especially from a surgical point of view.

\section{REFERENCES}

[1] Tobita M, Uysal AC, Ogawa R, Hyakusoku H, Mizuno H. Periodontal tissue regeneration with adipose-derived stem cells. Tissue Eng Part A 2008; 14(6): 945-53.
[2] Madden TE, Caton JG. Animal models for periodontal disease. Methods Enzymol 1994; 235: 106-19.

[3] Selvig KA. Discussion: animal models in reconstructive therapy. J Periodontol 1994; 65(12): 1169-72.

[4] Attstrom R, Graf-de Beer M, Schroeder HE. Clinical and histologic characteristics of normal gingiva in dogs. J Periodontal Res 1975; 10(3): 115-27.

[5] Schroeder HE, Attstrom R. Effect of mechanical plaque control on development of subgingival plaque and initial gingivitis in neutropenic dogs. Scand J Dent Res 1979; 87(4): 279-87.

[6] Lindhe J, Ericsson I. Effect of ligature placement and dental plaque on periodontal tissue breakdown in the dog. J Periodontol 1978; 49(7): 343-50.

[7] Soames JV, Davies RM. Lymphocyte-macrophage and lymphocyte-lymphocyte associations in early gingivitis in beagle dogs. J Periodontal Res 1980; 15(3): 341-4.

[8] Yamasaki A, Nikai H, Niitani K, Ijuhin N. Ultrastructure of the junctional epithelium of germfree rat gingiva. J Periodontol 1979; 50(12): 641-8.

[9] Peruzzo DC, Benatti BB, Antunes IB, et al. Chronic stress may modulate periodontal disease: a study in rats. J Periodontol 2008; 79(4): 697-704.

[10] Lallam-Laroye C, Escartin Q, Zlowodzki AS, et al. Periodontitis destructions are restored by synthetic glycosaminoglycan mimetic. J Biomed Mater Res A 2006; 79(3): 675-83.

[11] Caton J, Mota L, Gandini L, Laskaris B. Non-human primate models for testing the efficacy and safety of periodontal regeneration procedures. J Periodontol 1994; 65(12): 1143-50.

[12] Schou S, Holmstrup P, Kornman KS. Non-human primates used in studies of periodontal disease pathogenesis: a review of the literature. J Periodontol 1993; 64(6): 497-508.

[13] Giannobile WV, Finkelman RD, Lynch SE. Comparison of canine and non-human primate animal models for periodontal regenerative therapy: results following a single administration of PDGF/IGF-I. J Periodontol 1994; 65(12): 1158-68.

[14] Socransky SS, Haffajee AD. The bacterial etiology of destructive periodontal disease: current concepts. J Periodontol 1992; 63(4 Suppl): 322-31.

[15] Page R, Schroeder H. Periodontitis in man and other animals. a comparative review. Basel: Karger 1982.

[16] Blomlof L, Friskopp J, Appelgren R, Lindskog S, Hammarstrom L. Influence of granulation tissue, dental calculus and contaminated root cementum on periodontal wound healing. An experimental study in monkeys. J Clin Periodontol 1989; 16(1): 27-32.

[17] Ling LJ, Lai YH, Hwang H, Chen H. Response of regenerative tissues to plaque: a histological study in monkeys. J Periodontol 1994; 65(8): 781-7.

[18] Sculean A, Karring T, Theilade J, Lioubavina N. The regenerative potential of oxytalan fibers. an experimental study in the monkey. J Clin Periodontol 1997; 24(12): 932-6.

[19] Karatzas S, Zavras A, Greenspan D, Amar S. Histologic observations of periodontal wound healing after treatment with perioglas in nonhuman primates. Int J Periodontics Rest Dent 1999; 19(5): 48999.

[20] Drury GI, Yukna RA. Histologic evaluation of combining tetracycline and allogeneic freeze-dried bone on bone regeneration in experimental defects in baboons. J Periodontol 1991; 62(11): 652-8.

[21] Kostopoulos L, Karring T. Susceptibility of GTR-regenerated periodontal attachment to ligature-induced periodontitis. J Clin Periodontol 2004; 31(5): 336-40.

[22] Sculean A, Donos N, Brecx M, Karring T, Reich E. Healing of fenestration-type defects following treatment with guided tissue regeneration or enamel matrix proteins. an experimental study in monkeys. Clin Oral Investig 2000; 4(1): 50-6.

[23] Sculean A, Donos N, Brecx M, Reich E, Karring T. Treatment of intrabony defects with guided tissue regeneration and enamelmatrix-proteins. an experimental study in monkeys. J Clin Periodontol 2000; 27(7): 466-72.

[24] Donos N, Sculean A, Glavind L, Reich E, Karring T. Wound healing of degree III furcation involvements following guided tissue regeneration and/or Emdogain. a histologic study. J Clin Periodontol 2003; 30(12): 1061-8.

[25] Warrer L, Gotfredsen K, Hjorting-Hansen E, Karring T. Guided tissue regeneration ensures osseointegration of dental implants placed into extraction sockets. an experimental study in monkeys. Clin Oral Implants Res 1991; 2(4): 166-71. 
[26] Fritz ME, Braswell LD, Koth D, Jeffcoat M, Reddy M, Cotsonis G. Experimental peri-implantitis in consecutively placed, loaded rootform and plate-form implants in adult Macaca mulatta monkeys. J Periodontol 1997; 68(11): 1131-5.

[27] Hurzeler MB, Quinones CR, Schupbach P. Guided bone regeneration around dental implants in the atrophic alveolar ridge using a bioresorbable barrier. an experimental study in the monkey. Clin Oral Implants Res 1997; 8(4): 323-31.

[28] Hurzeler MB, Kohal RJ, Naghshbandi J, et al. Evaluation of a new bioresorbable barrier to facilitate guided bone regeneration around exposed implant threads. an experimental study in the monkey. Int J Oral Maxillofac Surg 1998; 27(4): 315-20.

[29] Schou S, Holmstrup P, Jorgensen T, Stoltze K, Hjorting-Hansen E, Wenzel A. Autogenous bone graft and ePTFE membrane in the treatment of peri-implantitis. I.clinical and radiographic observations in cynomolgus monkeys. Clin Oral Implants Res 2003; 14(4): 391-403.

[30] Schou S, Holmstrup P, Skovgaard LT, Stoltze K, Hjorting-Hansen E, Gundersen HJ. Autogenous bone graft and ePTFE membrane in the treatment of peri-implantitis. II. stereologic and histologic observations in cynomolgus monkeys. Clin Oral Implants Res 2003; 14(4): 404-11.

[31] Trejo PM, Bonaventura G, Weng D, Caffesse RG, Bragger U, Lang NP. Effect of mechanical and antiseptic therapy on peri-implant mucositis: an experimental study in monkeys. Clin Oral Implants Res 2006; 17(3): 294-304.

[32] Donos N, Glavind L, Karring T, Sculean A. Clinical evaluation of an enamel matrix derivative in the treatment of mandibular degree II furcation involvement: a 36-month case series. Int J Periodontics Restorative Dent 2003; 23(5): 507-12.

[33] Sorensen WP, Loe H, Ramfjord SP. Periodontal disease in the beagle dog: a cross sectional clinical study. J Periodontal Res 1980; 15(4): 380-9.

[34] Egelberg J. Local effect of diet on plaque formation and development of gingivitis in dogs. 3. effect of frequency of meals and tube feeding. Odontol Revy 1965; 16: 50-60.

[35] Egelberg J. Local effect of diet on plaque formation and development of gingivitis in dogs. I. effect of hard and soft diets. Odontol Revy 1965; 16: 31-41.

[36] Hamp SE, Lindhe J, Loe H. Experimental periodontitis in the beagle dog. J Periodontal Res 1972; 10: 13-4.

[37] Lindhe J, Hamp S, Loe H. Experimental periodontitis in the beagle dog. J Periodontal Res 1973; 8(1): 1-10.

[38] Hamp SE, Hamp M, Olsson SE, Lindberg R, Schauman P. Radiography of spontaneous periodontitis in dogs. J Periodontal Res 1997; 32(7): 589-97.

[39] Hamp SE, Lindberg R. Histopathology of spontaneous periodontitis in dogs. J Periodontal Res 1977; 12(1): 46-54.

[40] Page RC, Schroeder HE. Spontaneous chronic periodontitis in adult dogs: a clinical and histopathological survey. J Periodontol 1981; 52(2): 60-73.

[41] Haney JM, Zimmerman GJ, Wikesjo UM. Periodontal repair in dogs: evaluation of the natural disease model. J Clin Periodontol 1995; 22(3): 208-13.

[42] Wikesjo UM, Kean CJ, Zimmerman GJ. Periodontal repair in dogs: supraalveolar defect models for evaluation of safety and efficacy of periodontal reconstructive therapy. J Periodontol 1994; 65(12): 1151-7.

[43] Wikesjo UM, Selvig KA. Periodontal wound healing and regeneration. Periodontol 2000 1999; 19: 21-39.

[44] Araujo M, Berglundh T, Lindhe J. The periodontal tissues in healed degree III furcation defects. an experimental study in dogs. J Clin Periodontol 1996; 23(6): 532-41.

[45] Kim CK, Cho KS, Choi SH, Prewett A, Wikesjo UM. Periodontal repair in dogs: effect of allogenic freeze-dried demineralized bone matrix implants on alveolar bone and cementum regeneration. $\mathrm{J} \mathrm{Pe}-$ riodontol 1998; 69(1): 26-33.

[46] Koo KT, Polimeni G, Qahash M, Kim CK, Wikesjo UM. Periodontal repair in dogs: guided tissue regeneration enhances bone formation in sites implanted with a coral-derived calcium carbonate biomaterial. J Clin Periodontol 2005; 32(1): 104-10.

[47] Wikesjo UM, Lim WH, Razi SS, et al. Periodontal repair in dogs: a bioabsorbable calcium carbonate coral implant enhances space provision for alveolar bone regeneration in conjunction with guided tissue regeneration. J Periodontol 2003; 74(7): 957-64.
[48] Wikesjo UM, Qahash M, Thomson RC, et al. Space-providing expanded polytetrafluoroethylene devices define alveolar augmentation at dental implants induced by recombinant human bone morphogenetic protein 2 in an absorbable collagen sponge carrier. Clin Implant Dent Relat Res 2003; 5(2): 112-23.

[49] Wikesjo UM, Xiropaidis AV, Thomson RC, Cook AD, Selvig KA, Hardwick WR. Periodontal repair in dogs: rhBMP-2 significantly enhances bone formation under provisions for guided tissue regeneration. J Clin Periodontol 2003; 30(8): 705-14.

[50] Araujo MG, Berglundh T, Lindhe J. GTR treatment of degree III furcation defects with 2 different resorbable barriers: an experimental study in dogs. J Clin Periodontol 1998; 25(3): 253-9.

[51] Araujo MG, Lindhe J. GTR treatment of degree III furcation defects following application of enamel matrix proteins: an experimental study in dogs. J Clin Periodontol 1998; 25(6): 524-30.

[52] Araujo MG, Berglundh T, Albrekstsson T, Lindhe J. Bone formation in furcation defects: an experimental study in the dog. $\mathrm{J}$ Clin Periodontol 1999; 26(10): 643-52.

[53] Roriz VM, Souza SL, Taba M, Jr., Palioto DB, Grisi MF. Treatment of class III furcation defects with expanded polytetrafluoroethylene membrane associated or not with anorganic bone matrix/synthetic cell-binding peptide: a histologic and histomorphometric study in dogs. J Periodontol 2006; 77(3): 490-7.

[54] Fernandes JM, Rego RO, Spolidorio LC, Marcantonio RA, Marcantonio Junior E, Cirelli JA. Enamel matrix proteins associated with GTR and bioactive glass in the treatment of class III furcation in dogs. Braz Oral Res 2005; 19(3): 169-75.

[55] Onodera H, Shibukawa Y, Sugito H, Ota M, Yamada S. Periodontal regeneration in intrabony defects after application of enamel matrix proteins with guided tissue regeneration: an experimental study in dogs. Biomed Res 2005; 26(2): 69-77.

[56] Pimentel SP, Sallum AW, Saldanha JB, Casati MZ, Nociti FH, Jr. Sallum EA. Enamel matrix derivative versus guided tissue regeneration in the presence of nicotine: a histomorphometric study in dogs. J Clin Periodontol 2006; 33(12): 900-7.

[57] Sallum EA, Pimentel SP, Saldanha JB, et al. Enamel matrix derivative and guided tissue regeneration in the treatment of dehiscencetype defects: a histomorphometric study in dogs. J Periodontol 2004; 75(10): 1357-63.

[58] Saito E, Saito A, Kawanami M. Favorable healing following space creation in rhBMP-2-induced periodontal regeneration of horizontal circumferential defects in dogs with experimental periodontitis. J Periodontol 2003; 74(12): 1808-15.

[59] Miranda LA, Gomes SC, Soares IJ, Oppermann RV. A resinmodified glass ionomer cement barrier for treating degree II furcation defects: a pilot study in dogs. Acta Odontol Scand 2006; 64(1): 37-41.

[60] Sakata J, Abe H, Ohazama A, et al. Effects of combined treatment with porous bovine inorganic bone grafts and bilayer porcine collagen membrane on refractory one-wall intrabony defects. Int $\mathrm{J}$ Periodont Restorat Dent 2006; 26(2): 161-9.

[61] Kim CS, Choi SH, Chai JK, et al. Periodontal repair in surgically created intrabony defects in dogs: influence of the number of bone walls on healing response. J Periodontol 2004; 75(2): 229-35.

[62] Tal H, Pitaru S, Moses O, Kozlovsky A. Collagen gel and membrane in guided tissue regeneration in periodontal fenestration defects in dogs. J Clin Periodontol 1996; 23(1): 1-6.

[63] Tal H, Artzi Z, Moses O, Nemcovsky C, Kozlovsky A. Guided periodontal regeneration using bilayered collagen membranes and bovine bone mineral in fenestration defects in the canine. Int $\mathrm{J} \mathrm{Pe}$ riodont Restorat Dent 2005; 25(5): 509-18.

[64] Caplanis N, Lee MB, Zimmerman GJ, Selvig KA, Wikesjo UM. Effect of allogenic freeze-dried demineralized bone matrix on guided tissue regeneration in dogs. J Periodontol 1998; 69(8): 8516.

[65] Dogan A, Ozdemir A, Kubar A, Oygur T. Healing of artificial fenestration defects by seeding of fibroblast-like cells derived from regenerated periodontal ligament in a dog: a preliminary study. Tissue Eng 2003; 9(6): 1189-96.

[66] Klepp M, Hinrichs JE, Eastlund T, Schaffer EM. Histologic evaluation of demineralized freeze-dried bone allografts in barrier membrane covered periodontal fenestration wounds and ectopic sites in dogs. J Clin Periodontol 2004; 31(7): 534-44.

[67] Vastardis S, Yukna RA, Mayer ET, Atkinson BL. Periodontal regeneration with peptide-enhanced anorganic bone matrix in particulate and putty form in dogs. J Periodontol 2005; 76(10): 1690-6. 
[68] da Silva Pereira SL, Sallum AW, Casati MZ, et al. Comparison of bioabsorbable and non-resorbable membranes in the treatment of dehiscence-type defects: a histomorphometric study in dogs. J Periodontol 2000; 71(8): 1306-14.

[69] Weng D, Hurzeler MB, Quinones CR, Pechstadt B, Mota L, Caffesse RG. Healing patterns in recession defects treated with ePTFE membranes and with free connective tissue grafts: a histologic and histometric study in the beagle dog. J Clin Periodontol 1998; 25(3): 238-45.

[70] Casati MZ, Sallum EA, Caffesse RG, Nociti FH, Jr., Sallum AW, Pereira SL. Guided tissue regeneration with a bioabsorbable polylactic acid membrane in gingival recessions: a histometric study in dogs. J Periodontol 2000; 71(2): 238-48.

[71] Guiha R, el Khodeiry S, Mota L, Caffesse R. Histological evaluation of healing and revascularization of the subepithelial connective tissue graft. J Periodontol 2001; 72(4): 470-8.

[72] Kinoshita A, Oda S, Takahashi K, Yokota S, Ishikawa I. Periodontal regeneration by application of recombinant human bone morphogenetic protein-2 to horizontal circumferential defects created by experimental periodontitis in beagle dogs. J Periodontol 1997; 68(2): 103-9.

[73] Holland M, Boring JG, Boyle CR, Pickrum HM, Jeffcoat MK. Radiographic bone loss correlations and technetium-99m-MDP bone uptake in ligature-induced periodontal disease in the beagle. Vet Radiol Ultrasound 1998; 39(4): 366-74.

[74] Elharar F, Rodriguez HJ, Benque EP, Caffesse RG. Guided tissue regeneration with bioabsorbable and expanded polytetrafluoroethylene barrier membranes in the treatment of naturally occurring periodontal defects in dogs. J Periodontol 1998; 69(11): 1218-28.

[75] Lekovic V, Klokkevold PR, Kenney EB, Dimitrijelic B, Nedic M, Weinlaender M. Histologic evaluation of guided tissue regeneration using 4 barrier membranes: a comparative furcation study in dogs. J Periodontol 1998; 69(1): 54-61.

[76] Clergeau LP, Danan M, Clergeau-Guerithault S, Brion M. Healing response to anorganic bone implantation in periodontal intrabony defects in dogs. Part I. Bone regeneration: a microradiographic study. J Periodontol 1996; 67(2): 140-9.

[77] Hayashi C, Kinoshita A, Oda S, Mizutani K, Shirakata Y, Ishikawa I. Injectable calcium phosphate bone cement provides favorable space and a scaffold for periodontal regeneration in dogs. J Periodontol 2006; 77(6): 940-6.

[78] Mellonig JT, Nevins M, Sanchez R. Evaluation of a bioabsorbable physical barrier for guided bone regeneration. part II. material and a bone replacement graft. Int J Periodont Restorat Dent 1998; 18(2): 129-37.

[79] Mellonig JT, Nevins M, Sanchez R. Evaluation of a bioabsorbable physical barrier for guided bone regeneration. Part I. Material alone. Int J Periodont Restorat Dent 1998; 18(2): 139-49.

[80] Machado MA, Stefani CM, Sallum EA, Sallum AW, Tramontina VA, Nociti Junior FH. Treatment of ligature-induced periimplantitis defects by regenerative procedures: a clinical study in dogs. J Oral Sci 1999; 41(4): 181-5.

[81] Nociti FH, Jr., Caffesse RG, Sallum EA, Machado MA, Stefani CM, Sallum AW. Evaluation of guided bone regeneration and/or bone grafts in the treatment of ligature-induced peri-implantitis defects: a morphometric study in dogs. J Oral Implantol 2000; 26(4): 244-9.

[82] Nociti FH, Jr., Cesco De Toledo R, Machado MA, Stefani CM, Line SR, Goncalves RB. Clinical and microbiological evaluation of ligature-induced peri-implantitis and periodontitis in dogs. Clin Oral Implants Res 2001; 12(4): 295-300.

[83] Artzi Z, Givol N, Rohrer MD, Nemcovsky CE, Prasad HS, Tal H. Qualitative and quantitative expression of bovine bone mineral in experimental bone defects. Part 2: morphometric analysis. J Periodontol 2003; 74(8): 1153-60.

[84] Schwarz F, Herten M, Sager M, Bieling K, Sculean A, Becker J. Comparison of naturally occurring and ligature-induced periimplantitis bone defects in humans and dogs. Clin Oral Implants Res 2007; 18(2): 161-70.

[85] Hasegawa N, Kawaguchi H, Hirachi A, et al. Behavior of transplanted bone marrow-derived mesenchymal stem cells in periodontal defects. J Periodontol 2006; 77(6): 1003-7.

[86] Murano Y, Ota M, Katayama A, Sugito H, Shibukawa Y, Yamada S. Periodontal regeneration following transplantation of proliferating tissue derived from periodontal ligament into class III furcation defects in dogs. Biomed Res 2006; 27(3): 139-47.
[87] Mizuno H, Hata K, Kojima K, Bonassar LJ, Vacanti CA, Ueda M. A novel approach to regenerating periodontal tissue by grafting autologous cultured periosteum. Tissue Eng 2006; 12(5): 1227-335.

[88] Nakahara T, Nakamura T, Kobayashi E, et al. In situ tissue engineering of periodontal tissues by seeding with periodontal ligament-derived cells. Tissue Eng 2004; 10(3-4): 537-44.

[89] Listgarten MA. Similarity of epithelial relationships in the gingiva of rat and man. J Periodontol 1975; 46(11): 677-80.

[90] Guessous F, Huynh C, N'Guyen H, et al. An animal model for the assessment of gingival lesions. J Pharmacol Toxicol Methods 1994; 32(3): 161-7.

[91] Klausen B. Microbiological and immunological aspects of experimental periodontal disease in rats: a review article. J Periodontol 1991; 62(1): 59-73.

[92] Garant PR, Cho MI. Histopathogenesis of spontaneous periodontal disease in conventional rats. II. Ultrastructural features of the inflamed subepithelial connective tissue. J Periodontal Res 1979; 14(4): 310-22.

[93] Garant PR, Cho MI. Histopathogenesis of spontaneous periodontal disease in conventional rats. I. Histometric and histologic study. J Periodontal Res 1979; 14(4): 297-309.

[94] Listgarten MA, Johnson D, Nowotny A, Tanner AC, Socransky SS. Histopathology of periodontal disease in gnotobiotic rats monoinfected with Eikenella corrodens. J Periodontal Res 1978; 13(2): 134-48.

[95] King GN, King N, Cruchley AT, Wozney JM, Hughes FJ. Recombinant human bone morphogenetic protein-2 promotes wound healing in rat periodontal fenestration defects. J Dent Res 1997; 76(8): 1460-70.

[96] Huang KK, Shen C, Chiang CY, Hsieh YD, Fu E. Effects of bone morphogenetic protein- 6 on periodontal wound healing in a fenestration defect of rats. J Periodontal Res 2005; 40(1): 1-10.

[97] Nemcovsky CE, Zahavi S, Moses O, et al. Effect of enamel matrix protein derivative on healing of surgical supra-infrabony periodontal defects in the rat molar: a histomorphometric study. J Periodontol 2006; 77(6): 996-1002.

[98] Stavropoulos A, Kostopoulos L, Nyengaard JR, Karring T. Deproteinized bovine bone (Bio-Oss) and bioactive glass (Biogran) arrest bone formation when used as an adjunct to guided tissue regeneration (GTR): an experimental study in the rat. J Clin Periodontol 2003; 30(7): 636-43

[99] Eslami B, Behnia H, Javadi H, Khiabani KS, Saffar AS. Histopathologic comparison of normal and hyperplastic condyles. Oral Surg Oral Med Oral Pathol Oral Radiol Endod 2003; 96(6): 711-7.

[100] Eggert FM, Germain JP, Cohen B. The gingival epithelium of rodent molars with limited eruption. Acta Anat (Basel) 1980; 107(3): 297-306.

[101] Baron R, Saffar JL. A quantitative study of bone remodeling during experimental periodontal disease in the golden hamster. J Periodontal Res 1978; 13(4): 309-15.

[102] Harper DS, Mann PH, Regnier S. Measurement of dietary and dentifrice effects upon calculus accumulation rates in the domestic ferret. J Dent Res 1990; 69(2): 447-50.

[103] Mann PH, Harper DS, Regnier S. Reduction of calculus accumulation in domestic ferrets with two dentifrices containing pyrophosphate. J Dent Res 1990; 69(2): 451-3.

[104] Weinberg MA, Bral M. Laboratory animal models in periodontology. J Clin Periodontol 1999; 26(6): 335-40.

[105] Padgett GA, Leader RW, Gorham JR, O'Mary CC. The familial occurrence of the chediak-higashi syndrome in mink and cattle. Genetics 1964; 49: 505-12.

[106] Lavine WS, Page RC, Padgett GA. Host response in chronic periodontal disease. V. the dental and periodontal status of mink and mice affected by chediak-higashi syndrome. J Periodontol 1976; 47(11): 621-35.

[107] Gilmore ND, Glickman I. Some age changes in the periodontium of the albino mouse. J Dent Res 1959; 38: 1195-206.

[108] Cutress TW. Histopathology of periodontal disease in sheep. J Periodontol 1976; 47(11): 643-50.

[109] Aaboe M, Pinholt EM, Hjorting-Hansen E. Unicortical critical size defect of rabbit tibia is larger than $8 \mathrm{~mm}$. J Craniofac Surg 1994; 5(3): 201-3.

[110] Johnson MW, Sullivan SM, Rohrer M, Collier M. Regeneration of peri-implant infrabony defects using PerioGlas: a pilot study in rabbits. Int J Oral Maxillofac Implants 1997; 12(6): 835-9. 
[111] Schmitt JM, Buck DC, Joh SP, Lynch SE, Hollinger JO. Comparison of porous bone mineral and biologically active glass in criticalsized defects. J Periodontol 1997; 68(11): 1043-53.

[112] Takahashi D, Odajima T, Morita M, Kawanami M, Kato H. Formation and resolution of ankylosis under application of recombinant human bone morphogenetic protein-2 (rhBMP-2) to class III furcation defects in cats. J Periodontal Res 2005; 40(4): 299-305.

[113] Schliephake H, Aleyt J. Mandibular onlay grafting using prefabricated bone grafts with primary implant placement: an experimental study in minipigs. Int J Oral Maxillofac Implants 1998; 13(3): 38493.

[114] Craig RG, Kamer AR, Kallur SP, Inoue M, Tarnow DP. Effects of periodontal cell grafts and enamel matrix proteins on the implantconnective tissue interface: a pilot study in the minipig. J Oral Implantol 2006; 32(5): 228-36.

[115] Romanos GE, Henze M, Banihashemi S, Parsanejad HR, Winckler J, Nentwig GH. Removal of epithelium in periodontal pockets following diode $(980 \mathrm{~nm})$ laser application in the animal model: an in vitro study. Photomed Laser Surg 2004; 22(3): 177-83.

(C) Struillou et al.; Licensee Bentham Open.

This is an open access article licensed under the terms of the Creative Commons Attribution Non-Commercial License (http://creativecommons.org/licenses/by-nc/3.0/) which permits unrestricted, non-commercial use, distribution and reproduction in any medium, provided the work is properly cited. 